\title{
Digestibility and bioavailability of phosphorus from spray-dried yeasts in the diet of starting pigs $(15-30 \mathrm{~kg})$
}

\author{
Digestibilidade e biodisponibilidade do fósforo da levedura em dieta de suinos na fase \\ inicial $(15-30 \mathrm{~kg})$
}

\section{PEÑUELA SIERRA, Lina Maria ${ }^{1 *}$; MOREIRA, Ivan ${ }^{1}$; FURLAN, Antonio Claudio ${ }^{1}$; CARVALHO, Paulo Levi de Oliveira ${ }^{1}$; POVEDA PARRA, Ângela Rocio ${ }^{1}$; OLIVEIRA, Gisele Cristina ${ }^{1}$}

\author{
${ }^{1}$ Universidade Estadual de Maringá, Zootecnia, Centro de Ciências Agrárias, Departamento de Produção \\ Animal, Maringá, Paraná, Brasil. \\ *Endereço para correspondência: linapenuela@gmail.com
}

\section{SUMMARY}

Two experiments were carried out to determine the bioavailability of phosphorus in two spraydried yeasts - sugarcane yeast (SCY), and sugarcane yeast + brewer's yeast $(\mathrm{SCBY})-$ in starting pigs, by comparing different methods (Apparent Digestibility Coefficient of Phosphorus - ADCP; True Digestibility Coefficient of Phosphorus - TDCP; slope ratio; and standard curve). In experiment I, a digestibility assay were carried out using 30 cross breed pig with initial weigh of $22.69 \pm$ $4.24 \mathrm{~kg}$, allotted in a completely randomized design. The mean ADCP and TDCP values were 62.68 and $64.15 \%$ for SCY and 77.01 and $79.33 \%$ for SCBY. ADCP and TDCP for SCBY were higher $(\mathrm{P}<0.05)$ than the values for SCY. In Experiment II, a growth test was conducted, 56 crossbred piglets, were utilized, with initial live weight of $15.11 \pm 3.43 \mathrm{~kg}$, allotted in a completely randomized design, with seven treatments, four replications, and two pigs per experimental unit. The treatments consisted of a basal diet without supplementation with $\mathrm{P}$ and the same diet including supplementation with two levels of $\mathrm{P}(0.053 \%$ and $0.105 \%)$ from dicalcium phosphate, SCY and SCBY. The relative bioavailability mean value of $57.23 \%$ for SCY and $91.96 \%$ for SCBY, corresponding to $0.30 \%$ and $0.40 \%$ of available phosphorus, respectively.

Keywords: brewer's, piglets, slope ratio, standard curve, sugarcane

\section{RESUMO}

Foram conduzidos dois experimentos para determinar a biodisponibilidade do fósforo de duas leveduras secas por spray-dry, LEV35 = Cana-deaçúcar e LEV40 = Cana-de-açúcar+cervejaria para suínos na fase inicial, comparando diferentes metodologias (Coeficiente de Digestibilidade Aparente-CDAP e Verdadeira-CDVP do fósforo, Método da Relação dos Coeficientes de Regressão ou Slope Ratio e o Método da Curva Padrão). No Experimento I foi conduzido um ensaio de digestibilidade utilizando 30 leitões mestiços, com $22,69 \pm 4,24 \mathrm{~kg}$ de peso vivo, distribuídos em delineamento inteiramente casualizado. Os valores médios de CDAP e CDVP foram 62,68 e 64,15\% para a LVE35 e 77,01 e 79,33\% para a LEV40. Os CDAP e CDVP para a LEV40 foram maiores $(\mathrm{P}<0,05)$ que os valores da LEV35. No Experimento II foi conduzido um ensaio de crescimento, utilizando 56 leitões mestiços, com peso inicial de $15,11 \pm 3,43 \mathrm{~kg}$, distribuídos em delineamento inteiramente casualizado com sete tratamentos, quatro repetições e dois animais por unidade experimental. Os tratamentos consistiram de uma dieta basal sem suplementação de $\mathrm{P}$ e a mesma com suplementação de dois níveis de fósforo $(0,053$ e 0,105$)$ provenientes do fosfato bicálcico, LEV35 e LEV40. A biodisponibilidade relativa do fósforo foi diferente $(\mathrm{P}<0,05)$ para as duas leveduras, sendo o valor médio de $57,23 \%$ para a LEV35 e 91,96\% para a LEV40, o que corresponde a $0,30 \%$ e $0,40 \%$ de fósforo disponível, respectivamente.

Palavras chaves: cana de açúcar, cerveja, curva padrão, leitões, slope ratio, 


\section{INTRODUCTION}

Several different agro-industrial products and by-products have recently become available in the animal feed market, some of which are good nutrient sources for domestic animals (MOREIRA et al., 1998).

Brazil is currently the world's largest producer of sugarcane-based ethanol (CONAB, 2009). As one of the byproducts of ethanol processing, yeast has become quite important in animal diets. Meanwhile, Brazil's beer industry has expanded significantly, producing "brewer's yeast" as a by-product. Currently, as reported by Poveda-Parra et al. (2012ab), a new type of yeast is available in the market, produced from the mixture of both by-products (sugarcane yeast + brewer's yeast), which in turn has an intermediary protein level (40\%).

Several studies have confirmed that yeast is an important protein source, which can be used in different supplementation levels in the feeding of pigs (MOREIRA et al., 2002). According to Rostagno et al. (2005), total phosphorus values for sugar cane yeast and brewer's yeast are $0.82 \%$ and $0.78 \%$, respectively.

Nutritionists have sought to obtain data on the bioavailability of the nutrients from each ingredient in order to produce technically and economically balanced diets for pigs in the different stages of the production cycle (TEIXEIRA et al., 2004). However, studies on yeast phosphorus are scarce. Therefore, it is important to evaluate yeast phosphorus, as it is one of the most expensive minerals and has significant nutritional importance in the diet.

Non-ruminant diets in Brazil are formulated from plant-based ingredients, usually cereal grains, which feature more than half of their phosphorus content in phytate form with bioavailability varying between 18 and $60 \%$ (CROMWELL, 1979; JACQUES et al. 2003).

According to NRC (1998), phosphorus is the third most expensive nutrient after energy and protein in swine nutrition and feeding; therefore, it requires special attention. The most used phosphorus source in swine feeding is dicalcium phosphate, which is an excellent product but quite expensive.

Thus, the objective was to evaluate the bioavailability of phosphorus in spraydried yeasts (sugarcane yeast - SCY, and sugarcane yeast + brewer's yeast SCBY), through a study of digestibility and performance for starting pigs (15$30 \mathrm{~kg})$.

\section{MATERIALS AND METHODS}

Experiments were performed at the Pig Farming Sector of the Iguatemi Experimental Farm, of the Maringá University, state of Paraná-Brazil.

Two experiments were performed: one on total digestibility (Experiment 1) and another on performance (Experiment 2) of starting pigs. Two spray-dried yeasts were studied: (SCY = sugarcane yeast, and SCBY = sugarcane yeast + brewer's yeast), whose chemical compositions is given in Table 1, along with the other diets.

A total digestibility assay (Experiment I) was conducted in the period between March and April 2008. The study utilized 30 crossbred, commercial lineage castrated male pigs, with mean initial live weight of $22.8 \pm 2.02 \mathrm{~kg}$, individually penned in metabolism cages similar to those described by Pekas (1968) in a climate-controlled building. 
From all animals, 24 were fed the experimental diets. The treatments applied were: Basal Diet $=$ providing $0.26 \%$ of total $\mathrm{P} ; \mathrm{DCP}=$ dicalcium phosphate $(0.618 \%)$; SCY $=$ sugarcane yeast $(20.19 \%)$; SCBY $=$ mixed yeast (sugarcane yeast + brewer's yeast) $(24.42 \%)$. First, the basal diet was formulated, including corn, soybean meal, starch, soybean oil, limestone, salt, synthetic amino acids, mineral and vitamin supplement, containing $0.26 \%$ of total P, so as to meet the requirements according to Rostagno et al. (2005), except for phosphorus. Next, the other three diets were formulated (DCP, SCY and SCBY), in which each feed item provided $0.105 \% \mathrm{P}$ to the basal diet (Table 2).

Table 1 - Chemical composition (as-fed basis) ${ }^{1}$ of the foods used in experimental diets

\begin{tabular}{lcccc}
\hline \multirow{2}{*}{ Ingredients $^{3}$} & \multicolumn{4}{c}{ Chemical composition of the ingredients (\%) } \\
\cline { 2 - 5 } & Dry Matter & Crude Protein & Phosphorus & Calcium \\
\hline Corn & 86.96 & 8.26 & 0.19 & 0.04 \\
Soybean meal & 88.48 & 45.30 & 0.50 & 0.24 \\
Sugarcane yeast & 94.52 & 33.62 & 0.52 & 0.04 \\
Sugarcane yeast+brewer's yeast & 92.94 & 37.59 & 0.43 & 0.14 \\
Dicalcium phosphate & 91.67 & - & 17.0 & 22.0 \\
\hline
\end{tabular}

${ }^{\mathrm{T}}$ Analyses performed at the Maringá State University.

Table 2. Composition of experimental diets and diet with low level of phosphorus (Experiment 1)

\begin{tabular}{|c|c|c|c|c|c|}
\hline \multirow{2}{*}{ Ingredient } & \multicolumn{5}{|c|}{ Diets $^{1}$} \\
\hline & Basal & DCP & SCY & SCBY & Low $\mathrm{P}$ \\
\hline Corn & 37.42 & 37.42 & 37.42 & 37.42 & - \\
\hline Soybean meal & 33.92 & 33.92 & 33.92 & 33.92 & - \\
\hline Cornstarch & 24.95 & 24.33 & 4.756 & 0.526 & 40.06 \\
\hline Limestone & 1.646 & 1.646 & 1.646 & 1.646 & 1.850 \\
\hline Dicalcium phosphate & - & 0.618 & - & - & - \\
\hline $\mathrm{SCY}$ & - & - & 20.19 & - & - \\
\hline SCBY & - & - & - & 24.42 & - \\
\hline $\begin{array}{l}\text { Vitamin }+ \text { Mineral } \\
\text { premix }^{2}\end{array}$ & 0.500 & 0.500 & 0.500 & 0.500 & 0.070 \\
\hline Soybean oil & 1.000 & 1.000 & 1.000 & 1.000 & 4.000 \\
\hline Growth promoter, $\%^{3}$ & 0.050 & 0.050 & 0.050 & 0.050 & - \\
\hline Salt & 0.400 & 0.400 & 0.400 & 0.400 & 0.400 \\
\hline L-Lysine $\mathrm{HCl}, 99 \%$ & 0.078 & 0.078 & 0.078 & 0.078 & 0.250 \\
\hline DL- Methionine, $99 \%$ & 0.040 & 0.040 & 0.040 & 0.040 & 0.100 \\
\hline Sugar & - & - & - & - & 40.27 \\
\hline Rice hull & - & - & - & - & 3.000 \\
\hline Isolated soy protein & - & - & - & - & 10.00 \\
\hline Total & 100 & 100 & 100 & 100 & 100 \\
\hline \multicolumn{6}{|c|}{$\begin{array}{l}{ }^{1} \text { DCP }=\text { Dicalcium phosphate; SCY }=\text { sugarcane dried yeast; SCBY }=\text { brewer's dried yeast }+ \text { sugarcane } \\
\text { dried yeast dried; Low P = Dieta low in phosphorus, formulated to calculate endogenous losses of } \\
\text { phosphorus }{ }^{2} \text { Vitamin and mineral supplement for starting pigs, composition per kg of product: vitamin } \\
\text { A, 50.000 UI; vitamin D3, } 10.000 \mathrm{UI} \text {; vitamin E, 160mg; vitamin K3, 12mg; vitamin B1, 12mg; vitamin } \\
\text { B2, 20mg, vitamin B6, 12mg; vitamin B12, 100mcg; folic acid, 2.4mg; nicotinic acid, 140mg; } \\
\text { pantothenic acid, 88mg; biotin, 0.4mg; Choline, } 1.248 \mathrm{~g} \text {; Fe, 800mg; Cu, 800mg; Co, 3.2mg; Mn, 220mg; } \\
\left.\text { Zn, } 11.150 \mathrm{mg} \text {; Se, } 1.2 \mathrm{mg} \text {; I, 7.2mg; }{ }^{3} \text { Leucomag (leucomycin, } 30 \%\right)\end{array}$} \\
\hline
\end{tabular}


The experimental design was completely randomized, with four treatments and four replications per treatment. The digestibility assay lasted for 18 days, with 13 days for adaptation and five days of total feces collection.

In order to determine endogenous phosphorus loss excreted in feces, six pigs were given a diet (Table 3) with low phosphorus content $(0.06 \%)$. The dietary amount given to each animal was determined as a function of metabolic weight $\left(\mathrm{kg}^{0.75}\right)$. Feed was provided twice daily, at 8 a.m. and 3 p.m., with $2.5 \mathrm{ml}$ of water added to each gram of diet.

Table 3. Composition of experimental diets (Experiment 2)

\begin{tabular}{|c|c|c|c|c|c|c|c|}
\hline Treatment: & 1 & 2 & 3 & 4 & 5 & 6 & 7 \\
\hline Source P: & Basal & \multicolumn{2}{|c|}{$\mathrm{DCP}^{1}$} & \multicolumn{2}{|c|}{$\mathrm{SCY}^{2}$} & \multicolumn{2}{|c|}{$\mathrm{SCBY}^{3}$} \\
\hline P total, \%: & 0.261 & 0.315 & 0.367 & 0.315 & 0.367 & 0.315 & 0.367 \\
\hline $\mathrm{P}$ addition, \%: & 0 & 0.053 & 0.105 & 0.053 & 0.105 & 0.053 & 0.105 \\
\hline \multicolumn{8}{|l|}{ Ingredients } \\
\hline Corn & 37.42 & 37.42 & 37.42 & 37.42 & 37.42 & 37.42 & 37.42 \\
\hline Soybean meal & 33.92 & 33.92 & 33.92 & 33.92 & 33.92 & 33.92 & 33.92 \\
\hline Cornstarch & 1.650 & 1.650 & 1.650 & 1.650 & 1.650 & 1.650 & 1.650 \\
\hline Limestone & 24.82 & 24.51 & 24.20 & 14.63 & 4.63 & 12.50 & 0.400 \\
\hline Dicalcium phosphate & 0.120 & 0.430 & 0.740 & 0.120 & 0.120 & 0.120 & 0.120 \\
\hline $\mathrm{SCY}$ & - & - & - & 10.19 & 20.19 & - & - \\
\hline SCBY & - & - & - & - & - & 12.32 & 24.42 \\
\hline Soybean oil & 1.000 & 1.000 & 1.000 & 1.000 & 1.000 & 1.000 & 1.000 \\
\hline Salt & 0.400 & 0.400 & 0.400 & 0.400 & 0.400 & 0.400 & 0.400 \\
\hline L-Lysine $\mathrm{HCl}, 99 \%$ & 0.080 & 0.080 & 0.080 & 0.080 & 0.080 & 0.080 & 0.080 \\
\hline DL- Methionine, $99 \%$ & 0.040 & 0.040 & 0.040 & 0.040 & 0.040 & 0.040 & 0.040 \\
\hline Vitamin+Mineral premix ${ }^{4}$ & 0.500 & 0.500 & 0.500 & 0.500 & 0.500 & 0.500 & 0.500 \\
\hline Growth promoter, $\%^{5}$ & 0.050 & 0.050 & 0.050 & 0.050 & 0.050 & 0.050 & 0.050 \\
\hline Total & 100 & 100 & 100 & 100 & 100 & 100 & 100 \\
\hline
\end{tabular}

The total collection of feces method was applied using $2 \% \mathrm{Fe}_{2} \mathrm{O}_{3}$ as a marker to indicate the start and finish of collections. Samples were collected once a day, conditioned in plastic bags and stored at $-18^{\circ} \mathrm{C}$. Later, the samples were homogenized, dried in a forced-air oven at $55^{\circ} \mathrm{C}$ for 72 hours and ground to pass through a 1-mm sieve for laboratory tests.

Dry matter was determined according to the method described by Silva and
Queiroz (2006). The assay determined dry matter intake (kg/day), total phosphorus intake $(\mathrm{g} / \mathrm{d})$, phosphorus intake from the basal diet and evaluated sources $(\mathrm{g} / \mathrm{d})$, phosphorus provided by the source and by the basal diet $(\%)$, phosphorus in the diet and feces (\%), excreted phosphorus (g), and phosphorus excreted by the animals that received the low-phosphorus diet (endogenous phosphorus, g). The obtained data were applied in the 
formulas described by Sakomura and Rostagno (2007) to determine the apparent digestibility coefficient (ADCP) and true digestibility coefficient (TDCP) of phosphorus.

$\mathrm{ADCP}=($ total $\mathrm{P}$ intake - total $\mathrm{P}$ excreted)/ total $P$ intake

$\mathrm{TDCP}=($ total $\mathrm{P}$ intake $-($ total $\mathrm{P}$ excreted - endogenous $\mathrm{P})$ )/ total $\mathrm{P}$ intake

In the phosphorus bioavailability (Experiment II), fifty-six crossbred, commercial lineage piglets were utilized - half of them barrows and the other half females - with initial live weight of $15.11 \pm 3.43 \mathrm{~kg}$ and final live weight of $29.72 \pm 4.81 \mathrm{~kg}$.

Two animals were housed per pen in a nursery constructed of masonry with fiber-cement roofing, divided into three galleries with ten pens each. Pens $\left(1.32 \mathrm{~m}^{2}\right)$ were raised decks with plasticcoated, woven wire flooring. Pigs had ad libitum access to feed and water from self-feeders and nipple waterers throughout the entire experimental period.

A basal diet (Table 4) was formulated to meet all nutrient requirements for starting pigs, according to Rostagno et al. (2005), except for P.

The seven applied treatments (Table 4) were: Basal $=$ No phosphorus supplementation, containing $0.26 \%$ total $\mathrm{P} ; \mathrm{DCP}=$ Basal diet with $0.053 \% \mathrm{P}$ coming from dicalcium phosphate; DCP $=$ Basal diet with $0.105 \% \mathrm{P}$ coming from dicalcium phosphate; $\mathrm{SCY}=$ Basal diet with $0.053 \% \mathrm{P}$ coming from SCY; $\mathrm{SCY}=$ Basal diet with $0.105 \% \mathrm{P}$ coming from SCY; SCBY = Basal diet with $0.053 \% \mathrm{P}$ coming from SCBY; SCBY = Basal diet with $0.105 \% \mathrm{P}$ coming from SCBY.

Table 4. Mean values of phosphorus balance and of the apparent and true digestibility coefficients of phosphorus on diet and on SCY and SCBY ${ }^{1}$

\begin{tabular}{lcccc}
\hline \multirow{2}{*}{ Itens $^{3}$} & \multicolumn{3}{c}{ Diets $^{2}$} \\
\cline { 2 - 5 } & $\mathrm{B}$ & $\mathrm{B}+\mathrm{DCP}$ & $\mathrm{B}+\mathrm{SCY}$ & $\mathrm{B}+\mathrm{SCBY}$ \\
\hline Dry matter intake, g & 5409 & 4868 & 4819 & 4810 \\
Total P intake, g & 14.42 & 18.40 & 19.90 & 18.52 \\
Basal P intake, g & 14.42 & 13.70 & 15.12 & 15.07 \\
Source P intake, g & - & 4.700 & 4.786 & 3.454 \\
Excreted P, g & 4.831 & 5.689 & 6.856 & 5.846 \\
Excreted Endogenous P, g & 0.737 & 0.737 & 0.737 & 0.737 \\
Diet P, \% & 0.267 & 0.378 & 0.413 & 0.385 \\
Apparent DC diet P, \% & 66.39 & 69.08 & 65.55 & 68.41 \\
Total digestible apparent P intake, g & - & 12.71 & 13.04 & 12.67 \\
Apparent basal digestible P intake & - & 9.100 & 10.04 & 10.01 \\
Apparent source digestible P intake, g & - & 3.616 & 3.011 & 2.660 \\
Apparent DC source P, \% & - & 76.93 & 62.68 & 77.01 \\
True DC diet P, \% & 70.82 & 73.09 & 69.25 & 72.41 \\
True total digestible P intake, g & - & 13.45 & 13.78 & 13.41 \\
True basal digestible P intake, g & - & 9.702 & 10.71 & 10.67 \\
True source digestible P intake, g & - & 3.748 & 3.070 & 2.740 \\
True DC source P, \% & - & 79.75 & 64.15 & 79.33 \\
\hline
\end{tabular}

${ }^{1}$ Values obtained, considering the methodology of total fecal collection and starting phase ${ }^{2} \mathrm{~B}=\mathrm{Basal}$; DCP = Dicalcium phosphate; SCY = sugarcane dried yeast; SCBY = sugarcane dried yeast + brewer's dried yeast; ${ }^{3} \mathrm{P}=$ phosphorus; $\mathrm{DC}=$ Digestibility coefficients 
The animals were allotted in a completely randomized design, with seven treatments, four replications, and two pigs per experimental unit.

Feed and water were provided ad libitum throughout the entire experimental period. On the last day of the growth assay, all animals were bleeding via cranial vena cava for serum $\mathrm{P}$ analysis, by means of a photometric UV test with endpoint determination (Phosphate FS, Kovalent ${ }^{\circledR}$ ). On the same day, caudectomies were performed as described by Fossum (2009). Coccygeal vertebrae were separated from the skin and muscles, defatted, dried at $80^{\circ} \mathrm{C}$, placed on a muffle furnace at $600^{\circ} \mathrm{C}$ during four hours, and later analyzed to determine the levels of ash and $\mathrm{P}$ in the bones. Chemical analyses of the diets, feeds, ash and phosphorus in the bone were conducted according to the methods described by Silva and Queiroz (2006).

Phosphorus bioavailability was evaluated for SCY and SCBY using two methods ( $\underline{A}$ : standard curve method; and $\mathrm{B}$ : slope ratio method), as described by Sakomura and Rostagno (2007).

Method A (Standard curve method): Following the method described by Sakomura and Rostagno (2007), a standard line was devised in which the linear regression equation was determined based on $\mathrm{P}$ intake data from the standard diet $(\mathrm{X})$ and the dependent variables (daily feed intake -DFI, daily weight gain-DWG, feed:gain ratio conversion-F:G, ash and $\mathrm{P}$ in bone, and $\mathrm{P}$ in serum) (Y).

The standard line $(\mathrm{Y}=\mathrm{a}+\mathrm{bx})$ obtained was used to estimate bioavailability for a given result, based on the value (Y) of the parameter measured from the test source (SCY and SCBY). The corresponding amount of nutrient of the standard source (DCP) was calculated as well. The ratio between the two values
(SCY or SCBY by DCP) provided the comparative bioavailability of the nutrient in the respective test source (SCY or SCBY).

Method B (Slope Ratio): The data were adjusted by two mathematical models, namely: Devise simple linear regression equations for DCP, which was the standard source $\left(Y=a+b_{p} X_{p}\right)$, and for the yeasts, which were the tested sources $\left(Y=a+b_{t} X_{t}\right)$, being $Y$ (DFI, DWG, FC, Ash and $\mathrm{P}$ in bone, and $\mathrm{P}$ in serum) and $\mathrm{X}$ (P intake).

Devise multiple linear regression equations, which were determined considering $\mathrm{P}$ intake of the basal diet $\left(\mathrm{X}_{\mathrm{b}}\right)$ and of DCP $\left(\mathrm{X}_{\mathrm{p}}\right)$, SCY $\left(\mathrm{X}_{\mathrm{t} 1}\right)$ and SCBY $\left(X_{t 2}\right)$, and answers according to the model: $Y=a+b_{b} X_{b}+b_{p} X_{p}+b_{t} X_{t}$

Relative bioavailability of $\mathrm{P}$ (BAP) was calculated from the ratio of the regression coefficients (b), considering the $b$ of the standard (DCP) to be $100 \%$ : $\mathrm{BAP}=\mathrm{b}_{\mathrm{t}} / \mathrm{b}_{\mathrm{p}} \times 100$.

Data from the two experiments were subjected to ANOVA using the MIXED procedure (SAS Institute, 2004).

\section{RESULTS AND DISCUSSION}

In the digestibility assay (Experiment I), mean values of $P$ balance and of the apparent and true digestibility coefficients of $\mathrm{P}$ on the diets and on SCY and SCBY (Table 4) were used to calculate the values for ADCP, TDCP and BAP (Table 5). The mean values obtained for ADCP and TDCP of SCBY were higher $(\mathrm{P}<0.05)$ than those of SCY (Table 5).

In experiment I, high values and little variation were observed for ADCP and TDCP for both studied feeds (SCY and SCBY). This procedure was done based on Cromwell (1979) statement that the apparent digestibility of phosphorus is 
often used to estimate the bioavailability of $\mathrm{P}$ on feed, although it is of limited use unless data are corrected for endogenous excretion of $\mathrm{P}$ on feces.

The lower values observed in the ADCP $(62.68 \%)$ and TDCP $(64.15 \%)$ for SCY are similar to those found by Bünzen et al. (2008), who while working with dehydrated sugarcane yeast (SCY) found ADCP values of 61.22 and $55.42 \%$, and TDCP values of 69.07 and $65.30 \%$, for growing and finishing pigs, respectively. However, was observed that the values of the ADCP and TDCP in the two yeasts are high, which is explained by the low content of phytic acid in yeast (SAUVANT et al., 2003).

Table 5. The apparent (ADCP) and true (TDCP) digestibility coefficients and Relative bioavailability of $\mathrm{P}$ (BAP) in the sources

\begin{tabular}{lcccc}
\hline \multirow{2}{*}{ Source of phosphorus } & \multicolumn{2}{c}{ ADCP } & \multicolumn{2}{c}{ TDCP } \\
\cline { 2 - 5 } & Total collection (\%) & BAP (\%) & Total collection (\%) & BAP (\%) \\
\hline DCP & $76.81^{\mathrm{a}}$ & 100.0 & $79.79^{\mathrm{a}}$ & 100.0 \\
SCY & $62.68^{\mathrm{b}}$ & 81.60 & $64.15^{\mathrm{b}}$ & 80.40 \\
SCBY & $77.01^{\mathrm{a}}$ & 100.3 & $79.33^{\mathrm{a}}$ & 99.42 \\
\hline CV $(\%)^{2}$ & \multicolumn{2}{c}{8.59} & & \multicolumn{2}{c}{9.55} \\
\hline
\end{tabular}

Means with different letters in the same column differ $(\mathrm{P}<0.05)$ by Newman Keuls test.

${ }^{1}$ Was attributed to dicalcium phosphate the value of $100 \%$ to phosphorus bioavailability; ${ }^{2}$ Coefficient of variation.

The TDCP value for SCY (64.15\%) observed in this study is similar to that reported $(66.45 \%)$ by Rostagno et al. (2005), for the same type of yeast. This slight difference in the digestibility coefficient of this co-product may be explained by variations in the processing parameters of yeast production, as they can influence nutrient availability (ZANUTTO et al., 1999).

The mean values obtained for ADCP and TDCP of SCBY were higher $(\mathrm{P}<0.05)$ than those of SCY (Table 6), showing values of ADCP and TDCP of $62.68 \%$ and $64.15 \%$ for SCY and $77.01 \%$ and $79.33 \%$ for SCBY respectively.

The BAP values calculated from the ADCP and TDCP were $81.6 \%$ and $80.4 \%$ for SCY and $100.26 \%$ and $99.42 \%$ for SCBY respectively (Table $5)$.

The differences observed for the digestibility coefficients of SCY and
SCBY (Table 5), in which SCBY coefficients are higher than those for SCY, can be explained by the description provided by Yamada et al. (2003). These authors affirm that the digestibility of integral cells of brewer's yeast is superior to that of yeast cells from ethanol distilling, because the cell walls (Composed of mannanoproteins and glucans) of yeast cells from ethanol distilling become thicker and more resistant to digestive enzymes, impairing enzyme proteolysis in integral cells, in addition to other factors such as different strains and animal metabolism, which may also have some influence. Moreover, according to Pansu et al. (1993) factors inherent to the source, such as mineral origin, physicalchemical structure, as well as exposed particle surface and technological treatments may increase or decrease the digestibility and bioavailability of a mineral, and alter its amounts excreted in feces. 
TDCP is also considered important to find BAP values. According to Shen et al. (2002), one must consider the endogenous losses of $\mathrm{P}$ that occur through mucus, desquamated cells and enzymes, in order to determine phosphorus digestibility coefficients, as these components represent an important path of excretion of this mineral and endogenous losses are more expressive in ingredients with low phosphorus levels. These authors further suggest that ADCP values of items such as corn may underestimate the true utilization of phosphorus by approximately $35 \%$. Thus, a growth assay is recommended to evaluate the bioavailability of $\mathrm{P}$ from several sources.

In recent studies, Moreira et al. (2009) says the simple superphosphate is the phosphorus source with the smallest capacity for polluting the environment, best bioavailability and most efficient use for the metabolism of growing pigs. The results values of Phosphorus bioavailability assay (Experiment II), there was no difference $(\mathrm{P}>0.05)$ in DFI, DWG and FC among the diets supplemented with two levels $(0.053$ and 0.105 ) of phosphorus from the tested sources (DCP, SCY and SCBY) (Table 6).

Table 6. Effect of level and intake of dietary phosphorus on performance, bone characteristics (bone ash- BA\%, bone phosphorus- BP\%) and serum phosphorus (SP $\mathrm{mg} / \mathrm{dL}$ ) in pigs

\begin{tabular}{|c|c|c|c|c|c|c|c|c|c|c|}
\hline \multirow[b]{2}{*}{$\mathrm{TR}^{2}$} & \multirow[b]{2}{*}{$\operatorname{Diet}^{1}$} & \multirow[b]{2}{*}{$\begin{array}{c}\text { Added } \\
\text { P \% }\end{array}$} & \multicolumn{2}{|c|}{ P Intake (g/day) } & \multicolumn{6}{|c|}{ Variables } \\
\hline & & & Basal & Source & $\begin{array}{c}\text { DFI. } \\
\text { kg/Day }\end{array}$ & $\begin{array}{l}\text { DWG. } \\
\mathrm{kg} / \text { day }\end{array}$ & $F: G$ & BA \% & ВP \% & $\begin{array}{c}\mathrm{SP} \\
\mathrm{mg} / \mathrm{dL}\end{array}$ \\
\hline 1 & Basal & 0 & 2.50 & - & 0.955 & $0.365^{b}$ & $2.65^{\mathrm{a}}$ & $38.26^{\mathrm{c}}$ & $5.43^{c}$ & $4.51^{\mathrm{c}}$ \\
\hline 2 & $\mathrm{DCP}$ & 0.053 & 3.16 & 0.639 & 1.206 & $0.507^{\mathrm{a}}$ & $2.40^{\mathrm{ab}}$ & $42.10^{\mathrm{abc}}$ & $6.70^{\mathrm{ab}}$ & $6.04^{b}$ \\
\hline 3 & & 0.105 & 2.94 & 1.182 & 1.125 & $0.497^{\mathrm{a}}$ & $2.26^{\mathrm{ab}}$ & $47.26^{\mathrm{a}}$ & $7.21^{\mathrm{a}}$ & $7.27^{\mathrm{a}}$ \\
\hline 4 & $\mathrm{SCY}$ & 0.053 & 2.80 & 0.567 & 1.069 & $0.439^{\mathrm{ab}}$ & $2.47^{\mathrm{ab}}$ & $40.64^{\mathrm{bc}}$ & $6.06^{\mathrm{bc}}$ & $4.88^{\mathrm{c}}$ \\
\hline 5 & & 0.105 & 2.82 & 1.131 & 1.076 & $0.484^{\mathrm{ab}}$ & $2.22^{\mathrm{ab}}$ & $39.02^{c}$ & $6.40^{\mathrm{abc}}$ & $6.24^{\mathrm{b}}$ \\
\hline 6 & SCBY & 0.053 & 2.94 & 0.595 & 1.123 & $0.478^{\mathrm{ab}}$ & $2.35^{\mathrm{ab}}$ & $41.64^{\mathrm{abc}}$ & $6.37^{\mathrm{abc}}$ & $5.99^{\mathrm{b}}$ \\
\hline 7 & & 0.105 & 2.82 & 1.132 & 1.077 & $0.515^{\mathrm{a}}$ & $2.10^{\mathrm{b}}$ & $45.11^{\mathrm{ab}}$ & $6.96^{\mathrm{ab}}$ & $7.05^{\mathrm{ab}}$ \\
\hline \multicolumn{2}{|c|}{$\mathrm{CV}(\%)$} & & & & 9.55 & 10.84 & 10.88 & 5.77 & 6.27 & 7.62 \\
\hline \multicolumn{2}{|c|}{ Mean } & & & & 1.09 & 0.47 & 2.35 & 42.0 & 6.45 & 5.99 \\
\hline
\end{tabular}

With regard to ash in bone, a difference $(\mathrm{P}<0.05)$ was observed the $0,105 \%$ level of SCBY compared to the same level of SCY, with inferior results for SCY always. $\mathrm{P}$ levels in bone were similar $(\mathrm{P}>0.05)$ for SCY and SCBY. However, $\mathrm{P}$ levels in serum were inferior $(\mathrm{P}<0.05)$ for the $0.053 \%$ level of SCY compared to the same level of SCBY.
Significant differences were found between the bioavailability coefficients of SCY and SCBY using performance variables compared to bone variables (bone ash, bone $\mathrm{P}$ ) and blood variables (serum P) - (Tables 7, 8 and 9).

To create the standard curve (Table 7), dicalcium phosphate (DCP) was used as the standard source, according to Sakomura and Rostagno (2007), 
differently from the monocalcium phosphate used by Queiroz et al. (2008); even so, it was observed in both situations that performance variables were not sensitive enough to determine the bioavailability of $\mathrm{P}$.

Table 7. Values of relative bioavailability of phosphorus of DCP, SCY and SCBY, with the standard curve, using the variables of performance, bone ash, phosphorus in bone and phosphorus in serum

\begin{tabular}{|c|c|c|c|}
\hline \multirow{3}{*}{ Dependent Variables } & \multicolumn{3}{|c|}{ Relative bioavailability of phosphorus (\%) } \\
\hline & \multicolumn{3}{|c|}{ Phosphorus sources } \\
\hline & $\mathrm{DCP}^{1}$ & $\mathrm{SCY}^{2}$ & $\mathrm{SCBY}^{3}$ \\
\hline Weight gain $(g / \text { day })^{4}$ & 100 & 78.03 & 115.07 \\
\hline Feed:Gain ${ }^{5}$ & 100 & 93.57 & 147.67 \\
\hline Bone ash $(\%)^{6}$ & 100 & 37.74 & 82.82 \\
\hline Bone phosphorus $(\%)^{7}$ & 100 & 55.62 & 88.86 \\
\hline Serum phosphorus $(\mathrm{mg} / \mathrm{dL})^{8}$ & 100 & 53.79 & 93.36 \\
\hline \multicolumn{4}{|c|}{$\begin{array}{l}\text { Was attributed to dicalcium phosphate the value of } 100 \% \text { to phosphorus bioavailability; } \\
\text { SCY = sugarcane dried yeast; }{ }^{3} \mathrm{SCBY}=\text { sugarcane dried yeast }+ \text { brewer's dried yeast; Regression } \\
\text { equations for the standard source }(\mathrm{DCP}):{ }^{4} \mathrm{DWG}=0.383786+0.119174 \mathrm{x} 1\left(\mathrm{r}^{2}=0.46\right) ;{ }^{5} \mathrm{~F}: \mathrm{G}=2.6299- \\
\left.0.317796 \times 1 \mathrm{r}^{2}=0.45\right) ;{ }^{6} \mathrm{BA}=37.9375+7.58246 \times 1\left(\mathrm{r}^{2}=0.70\right) ;{ }^{7} \mathrm{BP}=5.5583+1.46441 \times 1 \quad\left(\mathrm{r}^{2}=0.69\right) \text {; } \\
\mathrm{B} \mathrm{SP}=4.49707+2.37758 \times 1\left(\mathrm{r}^{2}=0.90\right) .\end{array}$} \\
\hline
\end{tabular}

Dicalcium phosphate remained the standard source for the development of the linear (Table 8 ) and multiple (Table 9) regression equations.

Regardless of the method used, higher BAP values were obtained for yeasts when considering performance variables, in comparison to bone and blood variables. Whatever the method considered (Tables 7, 8 and 9), BAP values of $\mathrm{P}$ for SCBY are higher than for SCY.

Mean BAP values obtained from multiple linear regression equations and considering the variables bone $\mathrm{P}$ and serum $P$ (Table 9) were $55.44 \%$ for SCY and $91.9 \%$ for SCBY. Because of inaccuracy of performance and bone ash variables, the variables bone $P$ and serum $\mathrm{P}$ were utilized to estimate BAP of both yeasts (Table 10).

Mean BAP value was calculated using the data obtained from both methods (standard curve and slope ratio - simple and multiple regressions). Thus, mean BAP values for SCY and SCBY were estimated as $57.23 \%$ and $91.96 \%$, respectively (Table 10). Finally, by multiplying these values by the percentage of phosphorus from each yeast (Table 1) and dividing by 100 , available P levels were obtained: $0.30 \%$ for SCY and $0.40 \%$ for SCBY.

Performance variables (Experiment II) were greater for the higher $\mathrm{P}$ levels because the experimental diets were not isoproteic, which may have influenced the results, as the level of total lysine in the diets was higher when yeast was added (Table 3 ).

In bioavailability studies, according to Petersen et al. (2011) and Ekpe et al. (2002) the variables DWG, FC, bone ash and serum $P$ are useful to evaluate $P$ sources. However, the results of this experiment suggest that in studies where the experimental diets are not isoproteic and isocaloric, the performance variables are not reliable, with greater variation in the measurements of $\mathrm{P}$ in serum and bone. 
Rev. Bras. Saúde Prod. Anim., Salvador, v.14, n.2, p.308-321 abr./jun., 2013 http://www.rbspa.ufba.br ISSN 15199940

Table 10. Values of relative bioavailability of phosphorus for SCY and SCBY, obtained by the different methodologies used

\begin{tabular}{lcccc}
\hline \multicolumn{4}{c}{ Relative bioavailability of phosphorus (\%) } \\
\cline { 3 - 4 } Source $^{1}$ & \multirow{2}{*}{ Standard Curve } & \multicolumn{2}{c}{ Slope Ratio } & \multirow{2}{*}{ Average } \\
\cline { 3 - 4 } & & Simple Linear & Multiple Linear & \\
\hline SCY & 54.71 & 61.52 & 55.45 & 57.23 \\
SCBY & 91.11 & 92.87 & 91.90 & 91.96 \\
\hline
\end{tabular}

${ }^{1} \mathrm{SCY}=$ sugarcane dried yeast; SCBY = sugarcane dried yeast + brewer's dried yeast.

Queiroz et al. (2008) affirm that the bone ash variable shows greater response sensitivity in comparisons among $\mathrm{P}$ sources, although this variable did not provide the desired sensitivity in our study. Using the slope ratio method (simple linear regression) to evaluate the BAP of rock phosphates, Souza et al. (2009) concluded that this methodology can be use currently and is reliable in evaluating the phosphorus availability of several feed items. The similar BAP values (Tables 9, 10) for each of the yeasts, obtained using the two mathematical models in the slope ratio method - simple and multiple linear regression - were similar to those obtained by Traylor et al. (2005), who evaluated $\mathrm{P}$ bioavailability in meat and bone meal, using both mathematical models. Regardless of the methodology used values for the BAP of SCBY are higher compared to SCY.

The low bioavailability of P in SCY can be attributed to the resistance of the cell wall to digestive enzymes, as yeast cells from ethanol distilling become thicker, impairing proteolysis (YAMADA et al., 2003). However, Sauvant et al. (2003) affirm that phytic phosphorus content present in yeast represents only $10 \%$ of total P content; as such, a large percentage of phosphorus from this source can become available for animals.

The methodology of multiple linear regression was used with good results, by Gomes et al. (1989). Similarly, this study utilized several models similar to those used by Sands et al (2001) who studied the corn with and without phytase to estimate the relative bioavailability of phosphorus.

Mean BAP value was calculated using the data obtained from both methods (standard curve and slope ratio - simple and multiple regression), considering that, according to Sakomura and Rostagno (2007), the growth assays are indicated for feed BAP evaluation, whereas the digestibility assay is important to determine the amount of absorbed P.

Rostagno et al. (2005) indicate the values of available $\mathrm{P}$ for sugarcane yeast and brewer's yeast as $0.27 \%$ and $0.26 \%$, respectively in Brazilian tables. However, it is important to highlight that these values are the result of the multiplication of total $\mathrm{P}$ levels by the generic coefficient 0.33 , which is used for plant feedstuffs sources, and not obtained in specific bioavailability experiments.

In this context, the bioavailability and digestibility of phosphorus in spraydried sugarcane yeast + brewer's yeast (SCBY) are superior to those from sugarcane yeast (SCY) for starting pigs. The apparent and true digestibility coefficients in yeasts are $62.68 \%$ and $64.15 \%$ for SCY; $77.01 \%$ and $79.33 \%$ for SCBY, respectively. The relative bioavailability of $\mathrm{P}$ is $57.23 \%$ for SCY 
and $91.96 \%$ for SCBY, which represents $0.30 \%$ and $0.40 \%$ of available phosphorus, respectively. It is concluded that the SCY and SCBY has good availability of phosphorus, which should be taken into account when formulating rations using these two industry byproducts in pig feed.

\section{REFERENCES}

BÜNZEN, S.; ROSTAGNO, H.S.; LOPES, D.C.; HASHIMOTO, F.A.; GOMES, P.C.; APOLÔNIO, L.R. Digestibilidade do fósforo de alimentos de origem vegetal determinada em suínos em crescimento e terminação.

Revista Brasileira de Zootecnia, v.37, n.7, p.1236-1242, 2008.

\section{CONAB. Cana-de-açúcar Safra 2008} (Terceiro levantamento). Disponível em:

$<$ http://www.conab.gov.br/conabweb/do wnload/safra/3lev-cana.pdf $>$. Acesso:

20 mar. 2009.

CROMWELL, G.L. Availability of phosphorus in feedstuffs for swine. In: DISTILLER FEED RESEARCH CONFERENCE, Louisville, KY. Proceedings... Louisville, KY, 1979. v.34, n.40, p.40-50.

EKPE, E.D.; ZIJLSTRA, R.T.; PATIENCE, J.F. Digestible phosphorus requirement of grower pigs. Canidian Journal of Animal Science, v.82, n.4, p.541-549, 2002.

FOSSUM, T.W. Cirugía em pequeños animales. 3 ed. España: Acribia, 2009. $1610 \mathrm{p}$.

GOMES, P.C.; ROSTAGNO, H.S.; PEREIRA, J.A.; COSTA, P.M, de A.; TORRES, R. de A. Exigência de
Fósforo Total e disponível e sua disponibilidade em fosfatos de rochas para suínos na fase inicial (13 a $37 \mathrm{~kg}$ ). Revista Brasileira de Zootecnia, v.18, n.1, p.64-76, 1989.

JACQUES, K.A.; LYONS, T.P.; KELSALL, D.R. The alcohol textbook. $4^{\text {th }}$ ed. England: Nottingham University Press, 2003. 448p.

MOREIRA, I.; ANDREOTTI, F.L.; FURLAN, A.C.; SCAPINELLO, C.; MARTINS, E.M. Viabilidade da Utilização da Levedura de Recuperação (Saccharomyces spp.), Seca pelo Método Spray-Dry, na Alimentação de Leitões em Fase de Creche. Revista Brasileira de Zootecnia, v.27, n.2, p.319-324, 1998.

MOREIRA, I.; JÚNIOR, M.M.; FURLAN, A.C.; PATRICIO, V.M.I.; OLIVEIRA, G.C. Uso da Levedura Seca por "Spray-Dry" como Fonte de Proteína para Suínos em Crescimento e Terminação. Revista Brasileira de Zootecnia, v.31, n.2, p. 962-969, 2002.

MOREIRA, J.A.; VITTI, D.M.S.S.; TEIXEIRA, A.O.; LOPES, J.B. Fisiologia digestiva de suínos alimentados com rações contendo diferentes fontes de fósforo. Revista Brasileira de Zootecnia, v.38, n.4, p.676-684, 2009.

NATIONAL ACADEMY OF SCIENCE - NRC. Nutrient

Requirements of Swine. 10th Washington, DC: National Academies Press, 1998.

PANSU, D.; DUFFUS, C.; BELLATON, C.; BRONNER, F. Solubility and intestinal transit time limit calcium absorption in rats. Journal of Nutrition, v.123, p.13961404, 1993. 
PEKAS, J.C. Versatile swine laboratory apparatus for physiologic and metabolic studies. Journal Animal Science, v.27, n.5. p.1303-1309, 1968.

PETERSEN, G.I.; PEDERSEN, M.D.; LINDEMANN, M.D.; STEIN, H.H. Relative bioavailability of phosphorus in inorganic phosphorus sources fed to growing pigs. Journal Animal Science, v.89, p.460-466, 2011.

POVEDA-PARRA, A.R.; MOREIRA, I.; FURLAN, A.C.; CARVALHO, P.L.O.; PEÑUELA-SIERRA, L.M.; FILHO, C.L. Levedura mista (cerveja + cana-de-açúcar) spray-dry na alimentação de leitões na fase inicial. Archivos de Zootecnia, v.62, p.199209, 2013a.

POVEDA-PARRA, A.R.; MOREIRA, I.; FURLAN, A.C.; CARVALHO P.L.O.; TOLEDO, J.B. Sugar cane spray dry yeast on growing and finishing pigs feeding. Arquivo Brasileiro de Medicina veterinária e Zootecnia, v.65, n.1, p.221-230, 2013b.

QUEIROZ, L.S.B.; BERTECHINI, A.G.; RODRIGUES, P.B.; GUERREIRO M.C. Utilização de fosfatos comerciais para frangos de corte na fase inicial. Pesquisa Agropecuária Brasileira, v.43, n.10, p.1421-1427, 2008.

ROSTAGNO, H.S.; ALBINO, L.F.T.; DONZELE, J.L. .; GOMES, P.C.; OLIVEIRA, R.F.; LOPES, D.C.; FERREIRA, A.S.; BARRETO, S.L.T.; EUCLIDES, R.F. Tabelas brasileiras para aves e suínos: composição de alimentos e exigências nutricionais. 2.ed. Viçosa:Universidade Federal de Viçosa, 2005. 186p.
SAKOMURA, N.K.; ROSTAGNO, H.S. Métodos de Pesquisa em nutrição de monogástricos. Jaboticabal: Funep, 2007. 283p.

SANDS, J.S.; RAGLAND, D.; BAXTER, C.; JOERN, B.C.; SAUBER, T.E.; ADEOLA, O. Phosphorus bioavailability, growth performance, and nutrient balance in pigs fed high available phosphorus corn and phytase.

Journal Animal Science, v.79, p.2134 2142, 2001.

SAS Institute. SAS ${ }^{\circledR}$ User's guide: statistics. Version 9.1.2. Cary, NC, USA, 2004.

SAUVANT, D.; PEREZ, J.M.; TRAN, G. Tablas de composición y de valor nutritivo de las matérias primas destinadas a los animales de interés ganadero. Paris: Institute National de la Recherche Agronomique, 2003. 212p.

SHEN, Y.; FAN, M.Z.; AJAKAIYE, A.; ARCHBOLD, T. Use of the regression analysis technique to determine the true phosphorus digestibility and the endogenous phosphorus output associated with corn in growing pigs. Journal of Nutrition, v.132, p.1199-1206, 2002.

SILVA, D.J.; QUEIROZ, A.C. Análise de alimentos: métodos químicos e biológicos. 3 ed. Viçosa, Universidade Federal de Viçosa, 2006. .235p.

SOUZA, L.W.; MORETTI, A.; TUCCI, F.M.; SOUZA, N.H.; LEAL, P.A.D.; HANZAI, N.H. Phosphorus availability of rock phosphates as compared with feed-grade phosphates for swine.

Revista Brasileira de Zootecnia, v.38, n.1, p.90-98, 2009. 
TEIXEIRA, A.; LOPES, D.C.; LOPES, J.B.; VITTI, D.M.S.; GOMES, P.C.; ROSTAGNO, H.S.; MOREIRA, J.A. INÁCIO, F. Determinação da biodisponibilidade do fósforo de Diferentes Fontes pela Técnica de Diluição Isotópica, em Suínos em Crescimento. Revista Brasileira de Zootecnia, v.33, n.5, p.1231-1237, 2004.

TRAYLOR, S.L.; CROMWELL, G.L.; LINDEMANN, M.D. Bioavailability of phosphorus in meat and bone meal for swine. Journal Animal Science, v.83, p.1054-1061, 2005.

YAMADA, E.A.; ALVIM, I.D.; SANTUCCI, M.C.C.; SGARBIERI, V.C. Composição centesimal e valor protéico de levedura residual da fermentação etanólica e de seus derivados. Revista de Nutrição, v.16, p.423-432, 2003.
ZANUTTO, C.A.; MOREIRA, I.; FURLAN, A.C.; SCAPINELLO, C.; MURAKAMI, A.E. Utilização de levedura de recuperação (Saccharomyces sp.) seca por "spray$d r y$ " ou por rolo rotativo na alimentação de leitões na fase inicial. Acta

Scientiarum, v.21, n.3, p.705-710, 1999.

Data de recebimento: $23 / 10 / 2012$

Data de aprovação: 18/04/2013 